\title{
PELAKSANAAN WE WENANG PERAWAT UNTUK KONSULTASI DAN KOLABORASI DENGAN DOKTER DALAM PELAYANAN KESEHATAN BERDASARKAN UNDANG - UNDANG NOMOR 38 TAHUN 2014 TENTANG KEPERAWATAN (Studi di RSUD Dr. Soedirman Kebumen) AHMAD ALFI MANALA
}

\begin{abstract}
ABSTRAK
Peran perawat adalah memberikan perawatan dan kenyamanan dimana perawat menjalankan fungsinya sebagai perawat spesifik, namun, peran perawat telah berubah menjadi lebih luas dengan penekanan pada peningkatan kesehatan dan pencegahan penyakit, serta memandang klien secara komprehensif.Perawat sebagai tenaga profesional bertanggung jawab dan berwenang memberikan pelayanan keperawatan secara mandiri, berkonsultasi dan berkolaborasi dengan tenaga kesehatan yang lain sesuai kewenangannya, terutama terkait dengan lingkup praktek dan perawat.

Penelitian ini bertujuan untuk menganalisaPelaksanaan wewenang Perawat Untuk Konsultasi dan Kolaborasi dengan Dokter berdasarkan Undang-Undang No. 38 Tahun 2014 Tentang Keperawatan di RSUD Dr. Soedirman Kebumen. Penelitian ini merupakan penelitian kualitatif dengan pendekatan yuridis sosiologis, pengambilan data secara kuisioner terhadap 30 perawat dan wawancara terhadap 4 orang nara sumber.

Hasil Penelitian menunjukan: bahwa Pelaksanaan wewenang Perawat untuk Konsultasi dan Kolaborasi dengan Dokter dalam Pelayanan Kesehatan di RSUD Dr Soedirman Kebumen sebagaimana disebutkan dalam Undang-undang Nomor 38 tahun 2014 tentang Keperawatan Pasal 30 ayat 1 yang menunjukan tidak efektif dilaksanakan. Hal ini dibuktikan masih banyaknya perawat yang tidak melakukan konsultasi dan kolaborasi dengan dokter dalam pelayanan kesehatan atau asuhan keperawatan. Terhadap tindakan pelanggaran tersebut dapat dikenakan sanksi disiplin yang ditentukan oleh Konsil Keperawatan sesuai dengan Pasal 49 dan 50 Undang-undang Nomor 38 Tahun 2014 tentang Keperawatan

Hambatan-hambatan dari pelaksanaan konsultasi dan kolaborasi perawat dengan dokter diantaranya adalah: Dalam Undang-undang Nomor 38 tahun 2014 tentang Keperawatan belum secara jelas menyebutkan tentang konsultasi dan kolaborasi seperti apa yang diharapkan, pembinaan dan pengawasan terhadap Perawat masih sangat kurang, tingkat pendidikan Perawat yang masih belum memadai, tingkat pengalaman Perawat yang belum banyak, keterbatasan dan kesibukan Dokter.

Kata kunci: perawat, kesehatan dan konseling
\end{abstract}

\section{ABSTRACT}

The nurse's role was caring and giving comfort to the client, which the nurse doing their position as a specific nurse, nowever, recently the nurse's role have being expanded into healthcare improvement and prevention of disease (prophylaxis), and also considering patient comprehensively. Nurse is demanded to have science and skill in all aspects of nursing care. Nurse as a proffesional employee, has some responsibility and authority to care and treat client independently, being able in consulting and collaborating with other health workers based on their authority, particularly related to the scope of nursing work.

This research is aimed at analysis of The Implementation of the Nurse's Authority to Consultate and Collaborate with The Doctor based on Law No. 38/2014 about Nursing which held in RSUD Dr. Soedirman Kebumen. This reseach is qualitative sociological juridical aproach, retrieval of data through observation, quisioner, the threty nurse and four informant.

This research result is represented that The Implementation of the Nurse's Authority to Consultate and Collaborate with The Doctor based on Law No. 38/2014 about Nursing section 30 of article 1 which held in RSUD Dr. Soedirman Kebumen, indicated to 'ineffective implementation'. This is evidenced that still many of nurses found 
did not do consultate and collaborate with the doctor or other health workers neither onto health service nor onto making the nursing care.

Therefore, related to this infringement of law, the Nursing Concil may determine discipline of sanction to the nurse, based on Law no. 38 / 2014 section 49 and 50 about Nursing.

The barrier and obstacle of the implementation of the nurse's authority to consultate and collaborate with the doctor onto health service are: 1 . The explanation of Law no. 38/2014 about what kind of expected consultation and collaboration between nurse and other health worker expecially with the doctor, is blurred. 2. Controlling and monitoring to the nurse's ethos of work is low. 3. Level of nurse's education is under qualify. 4. Low experience of Nurse. 5. Limited time related to rush hour of the doctor.

Keyword: nurse, healty, conseling

\section{A. Pendahuluan}

Kesehatan merupakan hal yang sangat berpengaruh terhadap seseorang dalam melaksanakan kegiatan hidup sehari-hari. Dengan kondisi tu-buh yang sehat, seseorang dapat melakukan berbagai macam aktifitas dalam rangka meningkat taraf hidupnya. Kesehatan menjadi sesuatu yang sangat berharga untuk terus tetap dijaga dan ditingkatkan. Hal tersebut tentulah tidak terlepas dari peran serta pemerintah, masyarakat dan tenaga kesehatan dalam menyelenggarakan pelayanan kesehatan yang sebaik-baiknya. Baik secara sendiri maupun bersama-sama untuk memelihara dan meningkatkan kesehatan, mencegah dan me-ngobati penyakit, serta memulihkan kesehatan seseorang, kelompok ataupun masyarakat.

Pada waktu lampau, peran perawat adalah memberikan perawatan dan kenyamanan karena pera-wat menjalankan fungsi perawat spesifik. Namun, peran perawat telah berubah menjadi lebih luas dengan penekanan pada pening-katan kesehatan dan pencegahan penyakit, juga memandang klien secara komprehensif.Dewasa ini, perawat dituntut memiliki pengetahuan dan keterampilan dalam berbagaibidang ${ }^{1}$.Perawat sebagai tenaga profesional bertanggung jawab dan berwenang memberikan keperawatan secara mandiri dan berkolaborasi dengan tenaga kesehatan sesuai kewenangannya, terutama terkait dengan lingkup praktik dan perawat.

Dalam penelitian yang dilakukan pada tahun 2014 oleh Ely Susanto, MBA didapatkan dari 95 orang yang menjadi responden sebesar 70 orang mengatakan ketidakpuasan terhadap pelayanan ruang Rawat Inap RSUD Kebumen disebabkan kemampuan petugas dan sarana-prasarana dan lingkungan pelayanan. 20 Orang menyatakan puas dengan seluruh proses pelayanan di Instalasi rawat

Cecep Triwibowo, 2010, Hukum Keperawatan, Panduan Hukum dan Etika Bagi Perawat, Pustaka Book Publisher, Yogyakarta, hlm. 34 
391 | J urnal Idea Hukum

Vol. 2 No. 2 Oktober 2016

Magister Hukum Fakultas Hukum Universitas J enderal Soedirman

inap RSUD Kebumen, sedangkan 5

orang mengatakan ragu-ragu akan

kepuasan atas pelayanan yang

diberikan oleh pihak Instalasi

Rawat Inap RSUD Kebumen. ${ }^{2}$ Dari data tersebut dapat disimpulkan bahwa rendahnya kualitas pelayanan Rawat Inap RSUD Kebumen adalah karena rendahnya kemampuan petugas dan minimnya sarana dan prasarana.

\section{B. PERUMUSAN MASALAH}

Melihat latar belakang tersebut, maka dapat dirumuskan permasalahan sebagai berikut:

1. Bagaimana pelaksanaan wewenang perawat untuk konsultasi dan kolaborasi dengan Dokter dalam pelayanan kesehatan berdasarkan Undang-Undang No. 38 Tahun 2014 Tentang Keperawatan di RSUD Dr. Soedirman Kebumen?

2. Hambatan-hambatan apa dalam Pelaksanaan konsultasi dan kolaborsi Dokter dan Perawat dalam pelayanan kesehatan di RSUD Dr. Soedirman Kebumen?

\section{Metode Penelitian}

Metode pendekatan yang digunakan dalam penelitian ini adalah menggunakan pendekatan yuridis sosiologis yang mengamati

2 Ely susanto, 2014, Kualitas Pelayanan Kesehatan Rumah Sakit Daerah Kebumen, http://etd.repository.ugm.ac.id diakses pada tanggal 17 November 2015 bagaimana reaksi dan interaksi yang terjadi ketika sistem norma itu bekerja di dalam masyarakat. ${ }^{3}$ Penelitian Yuridis Sosiologis digunakan untuk meneliti efektivitas bekerjanya hukum di dalam masyarakat sebagai bentuk interaksi antar aturan perundangan ketika dilaksanakan di dalam masyarakat. ${ }^{4}$ Penelitian ini menggunakanspesifikasi penelitian deskriptif, yaitu suatu penelitian yang bertujuan untuk menggambarkan keadaan atau gejala dari obyek yang akan diteliti tanpa bermaksud mengambil kesimpulan yang berlaku umum.Dikemukakan oleh Ronny Hanitijo Soemitro, bahwa:

Suatu penelitian deskriptif dimaksudkan untuk memberikan data yang seteliti mungkin tentang manusia, keadaan atau gejala-gejala lainnya dengan membatasi permasalahan dan pendekatannya. ${ }^{5}$ Penelitian ini dilakukan di RSUD Dr. Soedirman Kebumen.Responden dalam penelitian ini adalah perawat dalam bangsal rawat inap RSUD Dr Soedirman Kebumen yang berjumlah 30 orang responden. Pengambilan sampel dengan Random Sampling, serta sebagai nara sumber adalah Direktur RSUD Dr. Soedirman Kebumen, Ketua Komite Medis RSUD Dr. Soedirman Kebumen, Ketua komite Keperawatan RSUD

Mukti Fajar Nur Dewata dan Yulianto Achmad, 2010, Dualisme Penelitian Hukum Normatif dan Empiris, Yogyakarta: Pustaka Pelajar, hlm. 47.

4 Ibid, hlm. 52 Ibid, hlm. 166 
Dr. Soedirman Kebumen, Ketua keperawatan RSUD Dr. Soedirman Kebumen.

\section{Pembahasan}

1. Pelaksanaan wewenang Perawat untuk konsultasi dan kolaborasi dengan Dokter dalam Pelayanan kesehatan berdasarkan Undang-undang Nomor 38 Tahun 2014 tentang Keperawatan di RSUD Dr Soedirman Kebumen

Apabila dilihat dari pengetahuan perawat terhadap undangundang keperawatan maka hasil penelitian menggambarkan bahwa sebagian besar responden kurang mengetahui atau bahkan tidak tahu terhadap undang-undang tersebut. Hal ini dapat dibuktikan dengan melihat data yang dituangkan dalam tabel dibawah ini:

\section{Tabel 2 : Pengetahuan Terhadap Undang-Undang Nomor 38 Tahun 2014 tentang Keperawatan}

\begin{tabular}{|c|c|c|c|c|}
\hline $\begin{array}{l}\mathbf{N} \\
\mathbf{0} .\end{array}$ & $\begin{array}{c}\text { Inter } \\
\text { val } \\
\text { Kela } \\
\text { s }\end{array}$ & Kategori & $\begin{array}{c}\text { Frekuen } \\
\text { si } \\
\text { (F) }\end{array}$ & $\begin{array}{c}\text { Prose } \\
\text { ntase } \\
(\%)\end{array}$ \\
\hline 1 & $\begin{array}{c}5- \\
8\end{array}$ & $\begin{array}{l}\text { Tidak } \\
\text { Tahu }\end{array}$ & 9 & 30,00 \\
\hline 2 & $\begin{array}{l}9- \\
12\end{array}$ & Tahu & 15 & 50,00 \\
\hline 3 & $\begin{array}{c}13- \\
15\end{array}$ & $\begin{array}{c}\text { Sangat } \\
\text { Tahu }\end{array}$ & 6 & 20,00 \\
\hline \multicolumn{3}{|c|}{ TOTAL } & 30 & 100,00 \\
\hline
\end{tabular}

Tabel diatas mengungkapkan bahwa dari 30 responden terdapat 9 orang $(30,00 \%)$ responden menyata kan tidak mengetahui tentang undangundang keperawatan, dan sebanyak
15 orang $(50,00 \%)$ menyatakan mengetahui undang-undang tersebut, dan hanya sebanyak 6 orang $(20,00 \%)$ menyatakan sangatmengetahui tentang undang-undang keperawatan tersebut.

Kategori tidak tahu yaitu: jika Perawat sama sekali tidak mengetahui tentang Undang-undang Nomor 38 tahun 2014 tentang keperawatan. Kategori tahu yaitu: jika Perawat pernah mengeatahui, atau pernah mendengar tetapi belum begitu memahami tentang UU No. 38 tahun 2014 tentang keperawatan. Kategori sangat mengetahui: jika Perawat selain sudah mengetahui juga sudah sangat memahami tentang UU No. 38 tahun 2014 tentang keperawatan.

Dari kenyataan tersebut diatas, maka dapat disimpulkan bahwa masih banyak perawat yang sama sekali belum mengetahui tentang UUNo. 38 tahun 2014 tentang Keperawatan terutama tentang kewenangan perawat untuk konsultasi dan kolaborasi dengan dokter dalam pelayanan kesehatan. Artinya masih banyak perawat yang belum mengetahui tentang wewenang yang diberikan oleh undang-undang terhadap profesi perawat.Padahal menurut dalil yang dikemukakan oleh Robert B. Seidmen bahwasanya setiap peraturan hukum memberitahu tentang bagaimana seseorang pemegang peran diharapkan bertindak. Bagaimana seseorangpeme-gang peran itu akan bertindak sebagai suatu respon terhadap peraturan hukum merupakan 
393 | J urnal Idea Hukum

Vol. 2 No. 2 Oktober 2016

Magister Hukum Fakultas Hukum Universitas J enderal Soedirman

fungsi peraturan-peraturan yang di-

tujukan kepadanya, sanksi-sanksinya, aktivitasnya dari lembaga pelaksana serta keseluruhan kompleks sosial, politik dan lain-lainnya mengenai dirinya.

Tentang pengetahuan perawat tentang konsultasi dan kolaborasi dengan dokter dilihat dari hasil penelitian menggambarkan sebagaimana dituangkan dalm tabel dibawah ini:

Tabel 3 : Pengetahuan Perawat Terhadap Konsultasi dan Kolaborasi Dengan Dokter

\begin{tabular}{|c|c|c|l|c|}
\hline No. & $\begin{array}{c}\text { Interval } \\
\text { Kelas }\end{array}$ & Kategori & $\begin{array}{c}\text { Frekuensi } \\
\text { (F) }\end{array}$ & $\begin{array}{c}\text { Prosent } \\
(\mathbf{\%})\end{array}$ \\
\hline 1 & $15-18$ & $\begin{array}{c}\text { Tidak } \\
\text { Tahu }\end{array}$ & 3 & 10,00 \\
\hline 2 & $19-12$ & Tahu & 18 & 60,00 \\
\hline 3 & $23-26$ & $\begin{array}{c}\text { Sangat } \\
\text { Tahu }\end{array}$ & 9 & 30,00 \\
\hline \multicolumn{7}{|r|}{ TOTAL } & $\mathbf{3 0}$ & $\mathbf{1 0 0 , 0 0}$ \\
\hline
\end{tabular}

Dari tabel diatas dapat diungkapkan bahwa sebanyak 9 orang $(30 \%)$ reponden menyatakan sangat menge-tahui tentang konsultasi dan kolaborasi dengan dokter, dan sebanyak 18 orang menyatakan tahu tentang konsultasi dan kolaborasi dengan dokter, dan selanjutnya hanya ada 3 orang (10\%) menyatakan tidak mengetahui tentang Konsultasi dan Kolaborasi.

Kategori tidak tahu yaitu: jika perawat sama sekali tidakmengetahui tentang Konsultasi dan Kolaborasi dengan dokter. Kategori tahu yaitu: jika perawat pernah mengetahui, atau pernah mendengar tetapi belum begitu memahami ten-tang Konsultasi dan Kolaborasi de-ngan dokter. Kategori sangat menge-tahui jika Perawat selain sudah me-ngetahui juga sudah sangat me-mahami tentang Konsultasi dan Kolaborasi dengan dokter.

Dari kenyataan tersebut diatas, dapat ditarik kesimpulan bahwa tingkat pengetahuan perawat tentang konsultasi dan kolaborasi dengan dokter lebih baik dari pada tingkat pengetahuan terhadap undangundang Keperawatan. Walaupun masih kurang setidaknya dari 30 responden hanya ada 3 orang yang tidak mengetahui sama sekali. Hal ini mengandung arti bahwa perawat di wilayah RSUD dr Soedirman Kebumen mempunyai pengatahuan yang cukup tentang konsultasi dan kolaborasi dengan dokter.

Perawat sebagai tenaga
kesehatan seharusnya tetap
meningkatkan pengetahuannya. Hal tersebut dilakukan agar Perawat tetap bisa mengikuti perkembangan dalam dunia kesehatan. Dalam batang tubuh kode etik keperawatan disebutkan tanggung jawab Perawat terha-dap profesi Keperawatan. Perawat sebagai profesi Harus mampu mengikuti perkembangan 
ilmu dan teknologi yang terus

meningkat. $^{6}$

Selain meningkatkan ilmu pengetahuan Perawat juga dibekali cara berfikir yang kritis. Sehingga Perawat dapat memberikan alternatif penyelesaian masalah yang dihadapi pasien serta antisipasinya.Kompetensi yang harus dimiliki Perawat adalah perawat mampu mendefinisikan konsep etik dan mampu mendefinisikan masalah yang terjadi di pelayanan kesehatan, serta mampu menerapkan pelayanan keperawatan dengan memperhatikan sikap etik dengan menggunakan kode etik keperawatan sebagai pedoman.

Selanjutanya untuk mengetahui tentang pelaksanaan wewenang perawat untuk konsultasi dan kolaborasi dengan dokter dapat dilihat dari tabel dibawah ini:

Tabel 4 : Pelaksanaan Wewenang Perawat Untuk Konsultasi dan Kolaborasi Dengan Dokter

\begin{tabular}{|c|c|l|c|c|}
\hline No. & $\begin{array}{c}\text { Interval } \\
\text { Kelas }\end{array}$ & \multicolumn{1}{|c|}{ Kategori } & $\begin{array}{c}\text { Frek } \\
\text { (F) }\end{array}$ & $\begin{array}{c}\text { Prosent } \\
\text { (\%) }\end{array}$ \\
\hline 1 & $9-10$ & $\begin{array}{l}\text { Tidak pernah Konsultasi } \\
\text { \& Kolaborasi }\end{array}$ & 4 & 13,00 \\
\hline 2 & $11-12$ & $\begin{array}{l}\text { Kadang-kadang } \\
\text { Konsultasi \&Kolaborasi }\end{array}$ & 17 & 57,00 \\
\hline 3 & $13-14$ & $\begin{array}{l}\text { Selalu Konsultasi dan } \\
\text { Kolaborasi }\end{array}$ & 9 & 30,00 \\
\hline \multicolumn{2}{|r|}{ TOTAL } & $\mathbf{3 0}$ & $\mathbf{1 0 0 , 0 0}$ \\
\hline
\end{tabular}

Tabel diatas dapat mengungkapkan bahwa hanya 4 orang responden (13\%) menyatakan tidak

6 Cecep Triwibowo, 2014, Etika \& Hukum Kesehatan, Nuha Medika, Yogyakarta, hlm. 35 melakukan Konsultasi dan Kolaborasi, dan ada 17 orang responden $(57 \%)$ menyatakan Kadangkadang melakukan konsultasi dan kolaborasi, sedangkan sisanya 9 orang responden (30\%) menyatakan selalu melakukan konsultasi dan kolaborasi.

Kategori tidak pernah Konsultasi dan Kolaborasi yaitu: jika Perawat sama sekali tidak pernah melakukan Konsultasi dan Kolaborasi dengan Dokter dalam pelayanan kesehatan. Kategori kadang-kadang konsultasi dan kolaborasi yaitu: jika Perawat melakukan konsultasi hanya kadang-kadang atau tidak selalu Konsultasi dan Kolaborasi dengan Dokter dalam pelayanan kesehatan. Kategori sangat mengetahui jika Perawat selalu melakukan Konsultasi dan Kolaborasi dengan Dokter dalam pelayanan kesehatan.

Berdasarkan pada kenyataan tersebut diatas, maka dapat disimpulkan bahwa pelaksanaan konsultasi dan kolaborasi sudah berjalan walaupun pelaksanaanya masih kurang efektif. Oleh karena hasil penelitian yang demikian dapat dikatakan bahwa Perawat sudah ada yang melakukan konsultasi dan kolaborasi dengan dokter walaupun jumlahnya masih cukup sedikit atau belum seluruhnya melakukan.Konsekuensi dari hal tersebut adalah masih rendah 
395 | J urnal Idea Hukum

Vol. 2 No. 2 Oktober 2016

Magister Hukum Fakultas Hukum Universitas J enderal Soedirman

kualitas mutu pelayanan kesehatan

yang diberikan oleh perawat

terhadap pasien.

\section{Hambatan-hambatan dalam}

pelaksanaan konsultasi dan

kolaborasi Perawat dengan

Dokter dalam pelayanan

kesehatan di RSUD Dr.

\section{Soedirman Kebumen}

Berdasarkan hasil wawancara

yang dilakukan oleh penulis dengan beberapa kalangan yang terkait dengan pelaksanaan kosultasi dan kolaborasi perawat dengan dokter dalam pelayanan kesehatan di RSUD dr Soedirman Kebumen maka dapat dideskripsikan sebagai berikut:

Menurut Soeryono Soekanto, penegakan hukum terletak pada faktor-faktor yang mempengaruhinya, adapun faktor tersebut adalah:

1. Faktor hukumnya sendiri

2. Faktor penegak hukum

3. Faktor sarana

4. Faktor masyarakat dan kebudayaan

\section{Faktor hukumnya}

Hukum akan mudah ditegak kan, jika peraturan perundangundangannya sesuai dengan kebutuhan untuk terciptanya penyelenggaraan pelayanan publik, dan peraturan atau undang-undang bisa menjadi sumber hukum, jika berada dalam azas-azas sebagai berikut: tidak berlaku surut, dibuat oleh penguasa lebih tinggi, Undangundang yang bersifat khusus meniadakan undang-undang yang bersifat umum, undang-undang yang berlaku belakangan membatalkan yang berlaku terdahulu, dan undang-undang tidak dapat diganggugugat ${ }^{7}$. Faktor perundangundangan yang menghambat pelaksanaan konsultasi dan kolaborasi dengan dokter dalam pelayanan kesehatan diantaranya adalah:

Berdasarkan wawancara dengan nara sumber, dalam Undangundang Nomor 38 tahun 2014 belum secara jelas disebutkan tentang konsultasi dan kolaborasi yang seperti apa yang diharapkan atau yang sesuai dengan Undangundang tersebut. Hal itu menyebabkan pelaksanaan konsultasi dan kolaborasi tersebut belum bisa secara maksimal dilaksanakan oleh pemegang peran dalam hal ini adalah persawat.

\section{Penegak hukum}

Menurut Satjipto Raharjo, penegakan hukum pada hakikatnya merupakan penegakan ide-ide atau konsep-konsep yang abstrak itu, penegakan hukum adalah usaha untuk mewujudkan ide-ide tersebut

Ridwan J, 2012. Hukum Administrasi Negara dan Kebijakan Pelayanan Publik.Nuansa. Bandung. HIm 22 
menjadi kenyataan ${ }^{8}$. Jika hakikat penegakan hukum itu mewujudkan nilai-nilai atau kaidah-kaidah yang memuat keadilan dan kebenaran, maka penegakan hukum bukan hanya menjadi tugas dari para penegak hukum yang sudah dikenal secara konvensional.Akan tetapi menjadi tugas dari setiap orang. Meskipun demikian, dalam kaitanya dengan hukum publik, J.B.J.M. ten Berge mengatakan bahwa pihak peme-rintahlah yang paling bertanggung jawab melakukan penegakan hukum, De overheid is primair verantwooderlijk voor de handhaving van publiekrecht ${ }^{9}$.

Mentalitas petugas yang menegakan hukum (penegak hukum) antara lain mencakup hakim, polisi, jaksa, pembela, petugas pemasyarakatan, dan seterusnya. Apabila peraturan perundang-undangan sudah baik akan tetapi mental penegak hukum kurang baik, maka akan terjadi gangguan pada sistem penegakan hukum. Faktor penegak hukum yang menghambat pelaksanaan konsultasi dan kolaborasi perawat dengan dokter adalah:

Berdasarkan UU No. 38 tahun 2014 tentang Keperawatan yang berwenang melaksanakan pembinaan dan pengawasan terhadap praktik keperawatan

8 Satjipto Rahardjo, Masalah penegakan hukum suatu tinjauan sosiologis, bandung, sinar baru, hlm.15.

Ridwan.HR, Op. Cit, hlm 292-293. adalah peme-rintah, pemerintah daerah, konsil keperawatan dan organisasi profesi. Hal tersebut sesuai dengan bunyi Undangundang Nomor 38 tahun 2014 tentang Keperawatan (Pasal 55): Pemerintah, Pemerintah Daerah, Konsil keperawatan, dan Organisasi Profesi membina dan mengawasi Praktik Keperawatan sesuai dengan fungsi dan tugas masing-masing. (Pasal 56): pembinaan dan pengawasan Praktik Keperawatan sebagaimana dimaksud dalam Pasal 55 diarahkan untuk:

a. Meningkatkan mutu Pelayanan Keperawatan

b. Melindungi masyarakat atas tindakan Perawat yang tidak sesuai dengan standar; dan

c. Memberikan kepastian hukum bagi Perawat dan masyarakat.

Hasil wawancara dengan nara sumber diwilayah RSUD dr Soedirman Kebumen adalah: pembinaan dan pengawasan Perawat masih sangat kurang, baik itu pengawasan atau pembinaan di tingkat pemerintah, pemerintah daerah maupun pengawasan dari organisasi profesi. Badan atau lemabaga pengawasan dan pembinaan tersebut bertindak biasanya setelah ada kasus atau keluhan dari masyarakat. Padahal dalam suatu negara hukum pengawasan 
397 | J urnal Idea Hukum

Vol. 2 No. 2 Oktober 2016

Magister Hukum Fakultas Hukum Universitas J enderal Soedirman

\begin{abstract}
dan pembinaan tersebut
dimaksudkan untuk sebagai upaya

preventif atau upaya pencegahan

sebelum timbul masalah-maslah

tertentu. Dengan tidak

dilakukannya pembi-naan dan

pengawasan secar integral dan

menyeluruh pengaruhnya adalah di

tingkat kinerja Perawat di RSUD dr

Soedirman Kebumen kurang

maksimal dan mutu pelyanan

kesehatan terhadap pasien juga

kurang maksimal, hal ini juga akan

berdampak pada tingkat

kesembuhan pasien.
\end{abstract}

\section{Sarana atau fasilitas}

Fasilitas yang diharapkan untuk mendukung pelaksanaan hukum kalau peraturan perundangundangan sudah baik dan juga mentalitas penegaknya baik, akan tetapi fasilitas kurang memadai (dalam ukuran tertentu), maka penegakan hukum tidak akan berjalan dengan semestinya. Penye-lenggaraan pelayanan publik tidak akan berlangsung dengan lancar dan tertib, jika tanpa adanya sarana atau fasilitas yang mendukungnya. Sarana tersebut meliputi tenaga manusia yang berpendidikan, organisasi yang baik, peralatan yang memadai, dan keuangan yang cukup. Dari hasil wawancara dengan nara sumber adalah: tingkat pendidikan perawat yang masih belum sejajar yang terdiri dari pendidikan perawat SPK, D3, dan S1 keperawatan. Hal tersebut menyebabkan tingkat pengetahuan perawat yang belum sama. Kalau pendidikan yang baik itu akan mempengaruhi dalam pembentu-kan Critikal Thinking atau pola fikir. Kalo pendidikan SPK itu cenderung hanya tindakan saja tanpa ada pola fikir yang menyeluruh tentang penyakit yang diidap oleh pasien, berbeda dengan pendidikan D3 selain tindakan saja tetapi juga asuhan secara komperhensif atau menyeluruh. Terlebih pendidikan S1 keperawatan akan lebih mempunyai pola fikir yang kritis terhadap keadaan pasien tidak hanya melakukan suatu tindakan tetapi juga berfikir mengapa tindakan tersebut harus dilakukan juga alternatif tindakan yang lain guna meningkatakan mutu layanan terhadap pasien.

Tingkat pengalaman perawat juga bisa menjadi penghambat dalam pelaksanaan konsultasi dan kolaborasi dengan dokter. Perawat yang belum mempunyai pengalaman yang banyak akan cenderung kurang aktif dalam pelaksanaan pelayanan kesehatan. Sebaliknya perawat yang sudah berpengalaman akan lebih aktif dalam melaksanakan konsultasi dan kolaborasi dengan dokter, dan hal tersebut akan sangat berpengaruh terhadap mutu pelayanan yang diberikan. 
Selain dari perawat, hambatan konsultasi dan kolaborasi perawat dengan dokter juga dari dokter itu sendiri.Keterbatasan jumlah dokter spesialis yang ada dalam rumah sakit sangat mempengaruhi jalannya konsultasi dan kolaborasi. Dokter ketika melakukan visite atau kunjungan ke bangsal rawat inap sangat terbatas waktunya, karena mereka sudah ditunggui pasien baik itu di poli rawat jalan maupun di tempat praktik lain dokter tersebut. Karena banyak sekali dokter yang membuka praktek lebih dari satu tempat.Terlalu singkatnya waktu kunjungan ke pasien dibangsal sangat berpengaruh terhadap konsultasi dan kolaborasi, karena di situlah perawat dapat bertemu dengan dokter dan dapat berkonsultasi dan kolaborasi guna meningkatkan derajat mutu pelayanan kesehatan yang nantinya sangat mempengaruhi tingkat kesembuhan pasien.Seringkali perawat berkonsultasi hanya dengan dokter jaga di unit gawat darurat yang hanya dokter umum, hal ini jelas berpengaruh terhadap jalannya pelayanan kesehatan.

\section{Faktor \\ kebudayaan masyarakat}

Pada dasarnya penyelenggaraan pelayanan publik diperuntukan untuk masyarakat, karena masyarakatlah yang memerlukan berbagai pelayanan pemerintah se- bagai penguasa pemerintah.Tujuan utama pelayanan publik adalah untuk terciptanya kesejah-teraan masyarakat seutuhnya, maka masyarakat dapat mempe-ngaruhi terciptanya penye-lenggaraan pelayanan publik yang baik, artinya masyarakat harus mendukung kegiatan peningkatan pelayanan publik yang diaktuali-sasikan melalui kesadaran hukum.Indonesia memiliki masyarakat yang majemuk dengankarakteristik berbeda-beda, sehingga penye-lenggaraan pelayanan publik tidak bisa disamaratakan di masing masing daerah. Faktor kebudayaan dalam terciptanya penyelenggaraan pelayanan yang baik pada dasarnya mencakup nilai-nilai yang mendasari hukum yang berlaku, nilai-nilai konsepsi abstrak mengenai apa yang baik, layak dan buruk $^{10}$.

Hambatan yang dialami oleh perawat adalah belum adanya kesadaran masyarakat dalam memanfaatkan pelayanan kesehatan ditingkat pertama dalam hal ini adalah Puskesmas.Hal tersebut menyebabkan banyak pasien yang berbondong-bondong ke Rumah Sakit tanpa terlebih dahulu melakukan pemerikasaan ke Puskesmas.Padahal bisa dimungkinkan penyakit yang diderita oleh pasien

10 Ridwan J, 2012. Loc. Cit 
399 | J urnal Idea Hukum

Vol. 2 No. 2 Oktober 2016

Magister Hukum Fakultas Hukum Universitas J enderal Soedirman

tersebut bisa diatasi di Puskesmas

tanpa harus ke Rumah Sakit. Karena semakin banyak pasien yang pergi kerumah sakit dan jumlahnya tidak seimbang dengan jumlah dokter yang ada menyebabkan mutu atau kualitas layanan kesehatan akan berkurang.

Selain hal tersebut perawat juga mengalami hambatan tentang masih adanya anggapan dari masyarakat ataupun dari petugas kesehatan lain dalam hal ini adalah Dokter, yang menganggap Perawat hanyalah pesuruh atau pelengkap Dokter. Karena anggapan tersebut Perawat tidak diberi kewenangan untuk berkonsultasi dan kolaborasi dengan Dokter dalam melaksanakan pelayanan kesehatan. Padahal disebutkan dalam Undangundang Nomor 38 tahun 2014 tentang Keperawatan Pasal 1 (3) Pelayanan keperawatan adalah suatu bentuk pelayanan profesional yang merupakan bagian integral dari pelayanan kesehatan yang didasarkan pada ilmu dan kiat Keperawatan ditujukan kepada individu, keluarga, kelompok, atau masyarakat, baik sehat maupun sakit. Hal tersebut juga berdampak buruk pada kualitas atau mutu layanan kesehatan yang diberikan kepada masyarakat.

\section{E. Penutup}

\section{SIMPULAN}

Berdasarkan hasil penelitian dan pembahasan diatas, maka dapat disimpulkan sebagai berikut:

a. Pelaksanaan Wewenang Perawat untuk konsultasi dan kolaborasi dengan Dokter dalam pelayanan kesehatan di RSUD Dr Soedirman Kebumen sebagaimana disebutkan dalam Undang-undang Nomor 38 tahun 2014 tentang Keperawatan Pasal 30 ayat 1 yang menunjukan tidak efektif. Hal ini dibuktikan masih banyaknya Perawat yang tidak melakukan konsultasi dan kolaborasi dengan dokter dalam pelayanan kesehatan atau asuhan keperawatan. Yang disebabkan karena tidak mengetahui undang-undang keperawatan dan kewenangan perawat untuk konsultasi dan kolaborasi

b. Hambatan-hambatan dari pelaksanaan konsultasi dan kolaborasi perawat dengan dokter di RSUD Dr. Soedirman Kebumen adalah:

1) Faktor UU No. 38 tahun 2014 tentang Keperawatan belum secara jelas disebutkan tentang konsultasi dan kolaborasi seperti apa yang diharapkan

b) Faktor pembinaan dan pengawasan terhadap $\mathrm{Pe}$ rawat masih sangat kurang 
c) Faktor tingkat pendidikan Perawat yang masih belum memadai

d) Faktor tingkat pengalaman Perawat yang belum banyak

e) Faktor keterbatasan dan kesibukan Dokter

\section{Saran}

1) Dinas kesehatan dan dewan Direksi RSUD Dr Soedirman Kebumen:

a. Perlu Sosialisasi UU No. 38 tahun 2014 tentang Keperawatan secara berkala dan berkesinambungan

b. Perlu membuat peraturan untuk menjabarkan tentang konsultasi dan kolaborasi perawat dengan dokter

c. Perlu membuat tim pembina dan pengawas kinerja Perawat.

d. Penambahan jumlah Dokter, terutama Dokter Spesialis

2) Pengurus cabang dan ranting Persatuan Perawat Nasional Indonesia (PPNI)

a. Mengadakan pembinaan dan pengawasan secara intensif, baik teknis maupun administratif terhadap Perawat dilingkungan Rumah Sakit

b. Melakukan pelatihanpelatihan kemampuan

\author{
Perawat secara terus \\ menerus
}

3. Perawat; Untuk selalu disiplin dan patuh terhadap standar profesi dan kode etik Keperawatan.

4. Masyarakat; Untuk lebih memanfaatkan pelayanan kesehatan tingkat pertama atau Puskesmas

\section{DAFTAR PUSTAKA}

Agussalim. 2007. Pemerintah Daerah Kajian Politik Hukum. Jakarta: CV Ghalia Indonesia;

Atmosudirjo, Prajudi. 1981. Hukum Administrasi Negara. Bogor: Ghalia Indonesia;

Azwar, Azrul. 1996. Pengantar Administrasi Kesehatan. Binapura Aksara;

Buamona, Hasrul. 2015. Tanggung Jawab Pidana Dokter dalam Kesalahan Medis. Yogyakarta: Parama Publishing;

Budiarjo, Miriam. 1998. Dasar-dasar IImu Politik. Jakarta: Gramedia Pustaka Utama;

Darmadipura, M. Sajid. 2008. Kajian Bioetik 2005. Surabaya: Pusat Penerbit dan Percetakan UNAIR

Fajar Nur Dewata, Mukti dan Achmad, Yulianto. 2010. Dualisme Penelitian Hukum Normatif dan Empiris. Yogyakarta: Pustaka Pelajar.

Hanafiah, M. Sujuf. 2014. Etika Kedokteran \& Hukum Kesehatan. Jakarta: EGC;

Haryono Rudi. 2013. Etika Keperawatan dengan Pendekatan Praktis. Yogyakarta. Gosyen Publishing;

H.R, Ridwan. 2002. Hukum Adminsitrasi Negara. Yogyakarta: Penerbit UII Press:

HR, Ridwan. 2014. Hukum Administrasi Negara Edisi Revisi. Jakarta: PT, Raja Grafindo Persada

Ide Alexandra. 2012. Etika \& Hukum dalam Pelayanan Kesehatan. Yogyakarta: Grasia Book Publisher; 
401 | J urnal Idea Hukum

Vol. 2 No. 2 Oktober 2016

Magister Hukum Fakultas Hukum Universitas J enderal Soedirman

Machmud, Syahrul. 2012. Penegakan Hukum dan Perlindungan Hukum bagiDokter yang diduga Melakukan Medikal Malpraktek. Bandung: Karya Putra Darwati;

Marbun, S.F. 2011. Pengadilan Administrasi Negara dan Upaya Administrasi di Indonesia. Yogyakarta: FH UII Press;

Nasution, Bahder Johan. 2013. Hukum Kesehatan Pertanggung Jawaban Dokter. Jakarta: Rineka Cipta;

Priharjo Robert. 1995. Pengantar Etika Keperawatan. Yogyakarta. Kanisius;

-------,. 1980. Hukum dan Masyarakat. Bandung: Angkasa

------,Tanpa Tahun. Masalah Penegakan Hukum, Suatu Tinjaun Sosiologis. Bandung: Sinar Baru;

Rahardjo, Satjipto. 2009. Penegakan Hukum, Suatu Tinjauan Sosiologis. Yogyakarta: Genta Publishing;

Siswati, Sri. 2015. Etika dan Hukum Kesehatan dalam Prespektif Undang-undangKesehatan. Jakarta: PT Raja Grafindo Persada

Soekanto, Soerjono.2007. Faktor-faktor yang Mempengaruhi Penegakan Hukum. Jakarta: PT. Raja Grafindo;

Suherman, Ade Maman. 2004. Pengantar Perbandingan Sistem Hukum. Jakarta: Raja Grafindo Persada;

Susanto, I.S. Pembinaan Lembaga dan Pranata Hukum. Bahan Kuliah Bagi Mahasiswa Program MIH UNDIP Semarang 2002 dan Program MIH UNSOED Purwokerto 2003;

Syafrudin, Ateng. 2000. Menuju Penyelenggaraan Pemerintah Negara yang Bersih dan Bertanggung Jawab.J urnal Pro Jutisia Edisi IV. Bandung: Universitas Parahyangan;

Ta'adi, Ns. 2013. Hukum Kesehatan (Sanksi \& Motivasi bagi Perawat). Jakarta:Buku Kedokteran;

Triwibowo, Cecep. 2010. Hukum Keperawatan, Panduan Hukum dan Etika bagi Perawat. Yogyakarta: Pustaka Book Publisher;

Triwibowo, Cecep. 2014. Etika \& Hukum Kesehatan. Yogyakarta: Nuha Medika;
Chin Daek. 2014. Tanggung J awab Dan Tanggung Gugat Dalam Praktik Keperawatan. http://daekchin.blogspot.co.id. Diakses pada tanggal 21 Januari 2015.

Idtesis. Pengertian-Konsultasi-dibidangKesehatan. http://idtesis.com. Diakses tanggal 03 November 2015;

NN. Hubungan-perawat-dokter. https://chairulums.wordpress.com.

Diakses tanggal 03 November 2015;

NN. Pelimpahan Wewenang dalam Rancangan Undang-undang Keperawatan. https://shantidk.wordpress.com. Diakses pada tanggal 2 November 2015;

Nuwrileardkhiyari. 2013. Pengertian Supervisi.http:nuwrileardkhiyari.blo gdetik.com. diakses tanggal 04 November 2015;

M.J Nainggolan. 2010. Tinjauan Pustaka Supervisi.http:Repository.usu.ac.id. diakses tanggal 04 November2015.

Oechay. $2011 . \quad$ Manajemenkeperawatan-supervisi. https://oechayontheblog.blogspot.c om. Daiakses tanggal 04 November 2015;

Susanto Ely. 2014. Kualitas Pelayanan Kesehatan Rumah Sakit Umum DaerahKebumen. http://etd.repository.ac.id. Diakses pada tanggal 17 November 2015

Sora. N. 2014. Definisi atau Pengertian Supervisi dan Menurut Para Ahli. http:www.Pengertianku. net>umum. Diakses tanggal 04 November 2015; 